\title{
Reflections and Exploration of the Two-level Management System in Local Colleges and Universities
}

\author{
Baohua Cui \\ Economic Management Department, Jilin Agricultural University, Changchun,130118,China \\ email: cbhjlau@yeah.net
}

Keywords: local colleges and universities; two-level, management system

\begin{abstract}
The two-level management system is not only the optimal allocation of discipline resources but also the allocation of management rights and responsibilities. Under the new situation of development of higher education, the implementation of two-level management system reform has become the general trend of the times. This paper conducts reflection and exploration of the connotation and main content, the relationships, basic concepts and countermeasures of two-level management.
\end{abstract}

\section{Introduction}

The reform of the internal management system in China's colleges and universities is the theme of the times of modernization of higher education. The report of the 17th National Congress of the CPC proposes the strategic plan of "giving priority to education and establishing a powerful country for human resources". In order to promote and implement the strategic plan, The National Outline for Medium and Long-term Educational Reform and Development clearly proposes to establish modern university system and promote the development of higher education and construction of a powerful country of human resources through modern reform of systems and mechanisms. Constructing, promoting and implementing two-level management system has become the focus and breakthrough of reform during construction and reform of modern university system ${ }^{[1]}$.

\section{The Connotation and Main Content of Two-Level Management System Reform in Colleges and Universities}

Two-level management system means that colleges and universities integrate and optimize the educational resources according to certain goals and principles to develop two administrative levels of school and college, change the administrative functions of school sectors, clarify the responsibilities and rights of school and college and develop management model of macro decisions made by school, coordination among sectors and actual operation of school by decentralized management and management focus shift. The two-level management system reform is continuous adjustment of organization, structure, function, and scale changes of colleges and universities as well as the deep development based on the reform of original internal management system. It focuses on clarifying two-level management and reducing the focus of management to decentralize the management authority, adjust the scope of management, regularize management behaviors, establish effective operational mechanism of macro control by school and independent operation of school by college, promote the integration and development of subjects, motivate operation of 
various sectors and improve efficiency and level of running a school ${ }^{[2]}$. The main content of two-level management system reform is to focus on division of rights and responsibilities and conduct reform of human resources, finance, resources, affairs and other aspects based on clarifying the subjectivity of college.

\section{Relationships that Should be Handled During Implementation of Two-Level Management by School and College}

The relationship between school and the college

As the legal representative, school must play a decisive role in the macro aspects. It should focus more on studying strategic development and grasp its development orientation. As the specific contractor, school owns micro management power with decision-making and self-management rights. Besides, it owns human, financial and material resources to establish self-development and self-restraint mechanism. College can play its creativity and autonomy to improve the enthusiasm in teaching and research.

The relationship between functional departments and the college

The functional departments are necessary institutions to ensure the normal operation of school. They should exercise their administrative power within the scope of functions and duties. College should accept the guidance and supervision of functional departments and place emphasis on playing the basic, active and forward-looking role of its work ${ }^{[3]}$.

The relationship between administrative power and academic power

Academic power and administrative power is an important part of the internal management mechanism of colleges and universities. The implementation of two-level management system by colleges and universities means that they should position the academic and administrative power in a scientific and reasonable way, which is a key to improving management efficiency and quality of school operation, coordinating the relationship between different interest groups and functional departments and effectively improving the social functions of school. Only by establishing sound operational system can academic power play its role in two-level management system and improve the academic structure of school and college.

The relationship between development and stability

As the two-level management reform involves all aspects of school, there will be various problems in the process of reform. Therefore, school should adhere to the principle of dialectical unity and mutual promotion, fully implement the scientific outlook of development and unify the reform degree of school, development speed and tolerance of students, teachers and staff to promote reform and development in stability and promote stability through reform and development.

\section{Basic Ideas of the Reform of Two-Level Management System}

Shift of management focus - moderate coordination of centralization and decentralization of power

The reform of two-level management system is to develop a reasonable system, achieve moderate coordination of centralization and decentralization of power, narrow scope of management, distribute school-level operation pressure, motivate operation of college, improve efficiency of college management and enhance the overall competitiveness. In order to remain vertical and horizontal interactions of college organizations, they should grasp the degree of centralization and decentralization in order to ensure flexible and adaptable two-level management ${ }^{[4]}$. Two-level management system reform should construct corresponding power, 
functions and responsibilities of school and college to complement each other and develop self-restraint and self-development mechanism.

Self-management concept - good interaction between administrative power and academic power

In the reform of two-level management system, school should optimize administrative power. Then, it should confirm principal's responsibility system under the leadership of the party committee and manage top design as the legal representative. Besides, it should explore the development orientation and resource allocation from a strategic perspective, offer systems and policies and handle the external public affairs. College can obtain autonomous management power to implement autonomy, personnel right, allocation power, financial power and financing power according to the principle of decentralization, establish self-development and self-restraint mechanism and improve the effectiveness of operation. The functional departments should provide information and resources, implement necessary administrative power and guide, supervise and serve on behalf of the school ${ }^{[5]}$.

People-oriented concept - focus on incentives and restraint

In the reform process of two-level management system, schools should insist on the integration of responsibilities, powers and interests, establish remuneration, control, reputation and other incentive mechanisms and restraint mechanisms such as internal supervision and competition, maximize the enthusiasm of college and achieve common pursuit between school and college to enhance the overall core competitiveness. College with the autonomy should be people-oriented, motivate and play enthusiasm, initiative and creativity of teachers by personnel system and resource allocation, clarify common objectives of college, excavate the potential and contribute to the development of college. In addition, they should offer bigger power and responsibilities, participate into internal management and develop democratic channels. Moreover, they should create a good college culture, enhance communication and work together to promote development of college.

\section{Countermeasures to Improve Two-Level Management of School and College}

Follow logic of subject construction and optimize college settings

Following knowledge-based logic of subject can promote interactions among subjects, promote the development of disciplines and knowledge innovation and help cultivate interdisciplinary and compound talents. It is a basis for building a vibrant academic community and ecological environment. It is a major development trend to improve level of subject in college settings, remain college quantity within a favorable management scope, increase subject capacity of college and provide convenience for exchanges among adjacent subjects. Schools should achieve inter-disciplines, comprehensive disciplines, complementary advantages of disciplines and academic resources sharing and cultivate high quality talents of solid foundation, wide variety and strong adaptability by subject groups and advantage of big subject to improve teaching and scientific research of school.

Explore an effective management system of college

On the basis of clarifying the responsibilities of college party committee and school dean as the major executives, schools should implement the common responsibility system of party and administration, establish and improve party-government meeting system, regard party-government meeting as the important task of college and decide and implement the daily administrative work of college by school dean. School should set corresponding organizations as the core carrier of implementing academic power according to the conditions of colleges. The colleges should regard the college faculty congress and student congress as the major means of their democratic 
management. Besides, they should establish college consultation agencies jointly participated by college mates and others outside the school, such as committee of college events ${ }^{[6]}$.

Implement the autonomy of college and establish a reasonable operation and supervision system of power

The external management system of colleges and universities has a direct impact on the reform of internal management system. In practice, Chinese government has developed the identity and class of colleges and universities in the macroscopic level with a large degree of direct intervention of affairs of colleges and universities, resulting in same structure of internal organization and system of colleges and universities and the administrative functions of superior government for coping with the managerial behaviors of superior sectors. The core leadership of school tends to put main power and responsibilities in the level of school to reduce the risk of decentralization. As a result, the two-level management system reform takes a long time with little effect. The governmental sectors implement the autonomy of operation and establish a reasonable operation and supervision system of power. The system includes the compulsory rules developed by government and self-regulatory protocols developed by colleges and universities to avoid "kidnapping" the superior management sectors in implementation process of autonomy and other power abuse.

\section{Conclusion}

In a word, the current development of higher education in China has transited from external expansion to connotative development. The pure pursuit of size expansion cannot make the colleges and universities competitive but make them face the risk of elimination. Improving quality has become the most fundamental and urgent task of higher education reform and development. Implementing two-level management system is inevitable for connotative development and improving quality as well as the objective requirement and inevitable choice for establishing and improving modern university system.

\section{References}

[1] Yu Fujun,Wang Lijuan. The Thought and Practice of Two-class Management Mode in the Local University [J] . Journal of Anshan Normal University, 2012( 5) : 94-97.

[2] Wang Haili,Zhang Xing. Theory and practice of two-level management on university and its institutes $[\mathrm{J}]$. Journal of Chongqing Jiaotong University(Social Sciences Edition),2010(4): 100-103.

[3] Gu Hailiang. Perfecting the internal quality structure and constructing the modern university system [J]. China Higher Education, 2010(15-16): 18-20.

[4] Shen Xia. The reform and implementation of the decentralization system in the two level college [J]. Academic Exploration,2011(3): 210-212.

[5] Liu Yarong, Li Zhiming, Tang Ning. Research on the two level management mode of University and College [J] . Education \& Economy, 2010(2):12 - 15.

[6] Lin Jian. Division of power and responsibility in the two level management mode of University $[\mathrm{J}]$. Journal of National Academy of Education Administration, 2009( 11) : 37 43. 